\title{
Differences in Root Growth and Permeability in the Grafted Combinations of Dutch Tomato Cultivars (Starbuck and Maxifort) and Japanese Cultivars (Reiyo, Receive, and Magnet)
}

\author{
Tomomi Kakita, Ayami Abe, Takashi Ikeda* \\ School of Agriculture, Meiji University, Kawasaki, Japan \\ Email: ${ }^{*}$ agrisys@meiji.ac.jp
}

Received 10 September 2015; accepted 24 October 2015; published 27 October 2015

Copyright (C) 2015 by authors and Scientific Research Publishing Inc.

This work is licensed under the Creative Commons Attribution International License (CC BY). http://creativecommons.org/licenses/by/4.0/

(c) (i) Open Access

\begin{abstract}
Grafting is widely established in agriculture and provides practical advantages for vegetable production. We investigated physiological differences between the grafted combinations of Dutch (Starbuck and Maxifort) and Japanese (Reiyo, Receive and Magnet) tomato cultivars. Plants were grown hydroponically until the flowers on the first truss bloomed, and the following parameters were measured: fresh weight of the aerial parts, root surface area, root permeability (by using a pressure chamber), and water potential of exudates (by using an isopiestic psychrometer). The Starbuck/Maxifort combination had higher values of the aerial part weight, root surface area, and root permeability than Reiyo/Receive, whereas Reiyo/Maxifort tended to have higher values of these parameters than Reiyo/Receive and Reiyo/Magnet. Maxifort had a significantly larger root surface area than Receive, but root permeability was not significantly different. InReiyo/Maxifort and Starbuck/Receive, these parameters were not significantly different except for a single comparison of root permeability. Thus, root permeability and root surface area may depend not only on the rootstock but be also affected by scion in grafted plants. Water potential of exudates was similar in most combinations and experiments. This shows that three rootstock cultivars provided similar nutrient concentrations even with different scions.
\end{abstract}

\section{Keywords}

Isopiestic Psychrometer, Pressure Chamber, Root Surface, Water Potential

\footnotetext{
${ }^{*}$ Corresponding author.
}

How to cite this paper: Kakita, T., Abe, A. and Ikeda, T. (2015) Differences in Root Growth and Permeability in the Grafted Combinations of Dutch Tomato Cultivars (Starbuck and Maxifort) and Japanese Cultivars (Reiyo, Receive, and Magnet). American Journal of Plant Sciences, 6, 2640-2650. http://dx.doi.org/10.4236/ajps.2015.616266 


\section{Introduction}

Grafting is widely established in agriculture and provides practical advantages for vegetable production by increasing resistance to soilborne pathogens [1]-[4], tolerance to low root-zone temperatures [5]-[7], salinity tolerance [8]-[10], and endogenous hormone production [11]-[13]. In particular, increased salinity tolerance improves fruit yield of grafted tomato [8] [14]. Higher yield of grafted plants has been also observed in watermelon (Citrullus lanatus) [15] and in melon (Cucumismelo) [16] [17]. Increased plant growth and crop yield upon grafting in melon have been attributed to the increase in water and nutrient uptake due to the vigorous root systems of rootstocks [16]. Therefore, we think grafting would alter plant water relations.

We previously reported that seedlings of the Japanese cultivar Reiyo had higher root permeability to nutrient solution than those of the Dutch cultivar Dundee [18]; this study investigated only non-grafted plants, whereas most tomatoes in commercial production are grafted, including about $75 \%$ of the hydroponic tomatoes in the Netherlands [7]. However, the effect of grafting on root growth and permeability in Japanese and Dutch tomatoes has not been addressed. In this study, we used own-rooted Japanese and Dutch tomato cultivars and their grafted combinations to investigate how grafting affects root growth and permeability.

\section{Materials and Methods}

\subsection{Cultivars and Growing Conditions}

Two beef tomato (Solanum lycopersicum L.) cultivars, the Japanese cultivar Reiyo (Sakata Seed Co., Kanagawa, Japan) and the Dutch cultivar Starbuck (De Ruiter Seeds, Bleiswijk, the Netherlands) were usedas scions. Japanese cultivars Receive and Magnet (Sakata Seed Co.) and the Dutch cultivar Maxifort (S. lycopersicum $\times$ S. habrochaites) (De Ruiter Seeds) were used as rootstocks. Seeds were germinated in a dark incubator (HNM-S10; Koito Industries, Ltd., Kanagawa, Japan) at $25^{\circ} \mathrm{C}$. When root length reached 2 - $3 \mathrm{~mm}$, germinated seeds were transferred into commercial soil (Zen-Noh, Tokyo, Japan) in plug trays. Seedlings were grown in a glasshouse; the roof and side windows were opened when the internal temperature reached $25^{\circ} \mathrm{C}$ and the ceiling fan was activated at $30^{\circ} \mathrm{C}$. In winter, a heater was operated when the internal temperature became below $12^{\circ} \mathrm{C}$.

At the 4- to 5-leaf stage, Reiyo, Receive, Starbuck, and Maxifort were transplanted into a nutrient film hydroponic system (NFT) laid out to keep the root systems of each plant separate as described in Furukawa et al. [19] and Kakita et al. [20] (Figure 1). Plants of each cultivar were randomly placed $15 \mathrm{~cm}$ apart from each other. The nutrient solution (Otsuka-A; Otsuka Chemical Co., Ltd., Osaka, Japan) was adjusted to electrical conductivity (EC) of $2.2-2.4 \mathrm{dS} \cdot \mathrm{m}^{-1}$ and $\mathrm{pH}$ of $5.5-6.5$. Plants were pinched at two leaves above the primary flower cluster.

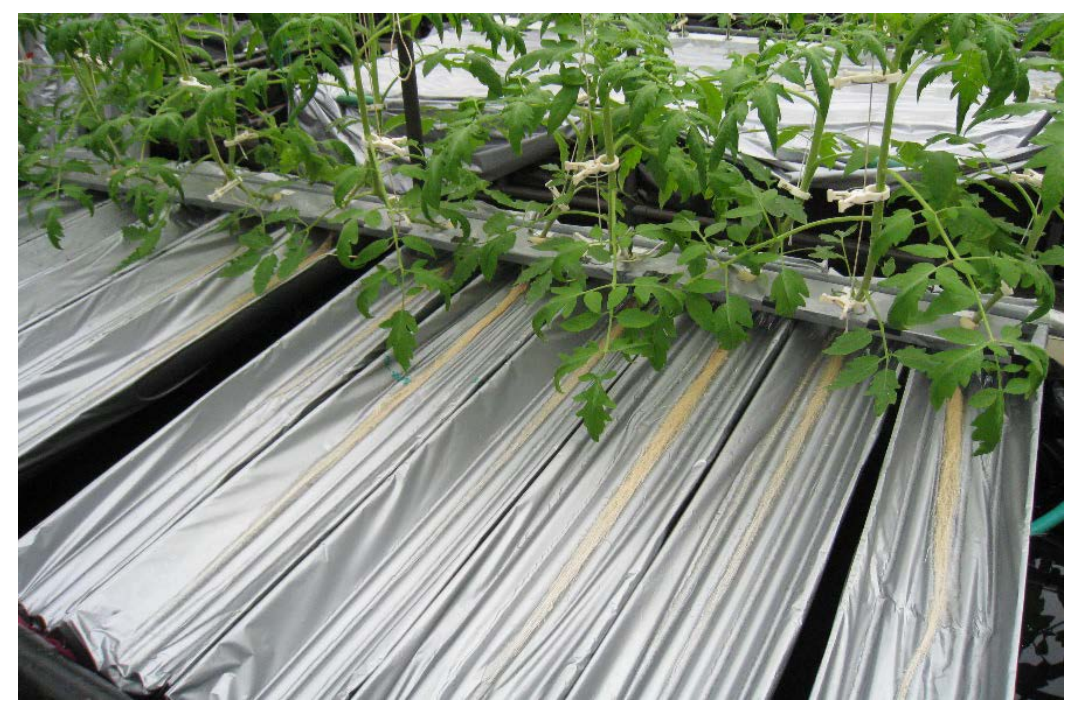

Figure 1. The hydroponic culture system (nutrient film technique, NFT) designed so that tomato roots do not grow over each other. Nutrient solution (EC 2.2 - 2.4 $\mathrm{dS} \cdot \mathrm{m}^{-1}$, pH 5.5 - 6.5) flowed along the slope near the plants. 


\subsection{Grafting}

Seedlings at the 3-leaf stage were used. Plants were cut diagonally at 30 degrees about $1 \mathrm{~cm}$ above the cotyledons and grafted with tubes (Nasunics Co., Ltd., Tochigi, Japan). The grafted seedlings were kept in the dark for 2 - 4 days and then acclimatized for 1 week to greenhouse conditions in plastic boxes $(62 \times 42 \times 22 \mathrm{~cm})$ with the tops lined with wet newspapers on the sides. The humidity was adjusted by spraying water on the newspapers, opening and closing the top, and using a shading net. During this period, plants were supplied with a nutrient solution with EC of $1.2 \mathrm{dS} \cdot \mathrm{m}^{-1}$ and $\mathrm{pH}$ of 5.5 - 6.5. At the 4- to 5-leaf stage, grafted plants were transplanted into the NFT system as described above. Plants used for the measurements grew in the NFT system until the flowers on the first truss bloomed. In Experiment 1, we prepared the grafted combinations Reiyo/Receive and Starbuck/Maxifort (scion/rootstock) and cultivated these plants from September to November 2011 ( $\mathrm{n}=10$ and 12, respectively), March to May 2012 ( $\mathrm{n}=8$ and 11), and October to January. 2012-2013 ( $\mathrm{n}=8$ for both combinations). In Experiment 2, we prepared the grafted combinations Reiyo/Maxifort and Starbuck/Receive and cultivated them from November to February 2011-2012 ( $\mathrm{n}=11$ and 8, respectively), April to June $2012(\mathrm{n}=10$ and 7), November to February 2012-2013 ( $\mathrm{n}=7$ and 8), and September to November ( $\mathrm{n}=6$ for both combinations). In Experiment 3, we grafted the Japanese scion Reiyoon to Receive, Magnet, and Starbuck. Plants were cultivated from September to January2013-2014 ( $\mathrm{n}=6$, 5, and 10, respectively) and November to February 2013-2014 ( $\mathrm{n}=5,7$, and 5).

\subsection{Determination of the Fresh Weight of the Aerial Parts, Root Surface Area, Root Permeability, and Exudate Water Potential}

After the flowers on the first truss bloomed, plants were cut near the cotyledons (non-grafted plants) or $2 \mathrm{~cm}$ above the graft union (grafted plants), and fresh aerial parts were weighed.

The root system of each plant was enclosed ( $1 \mathrm{~cm}$ below the cut) in a silicone rubber ring (38 $\mathrm{mm}$ outside diameter; $16 \mathrm{~mm}$ inside diameter), and the gaps between the ring and the stem were sealed with putty (EN ISO 4823, type 0 putty; Heraeus Kulzer-Japan, Tokyo, Japan). After the putty had set, the root system was fixed in a pressure chamber [18] [21] filled with nutrient solution (EC $2.4 \mathrm{dS} \cdot \mathrm{m}^{-1}$ ). The nutrient solution was forced into the roots under a pressure of $0.25 \mathrm{MPa}$ (permeability remained constant at $0.2-1.0 \mathrm{MPa}$; our unpublished data).The emerging exudate was discarded for the first 2 - 3 min and then absorbed on pre-weighed cotton for the next $2 \mathrm{~min}$; the difference in cotton weight before and after absorption was considered as the weight of the exudate. The root surface area was measured with a root scanner (WinRHIZO 2007; Regent Instruments Inc., Quebec, Canada) and used as a measure of root growth. Root permeability was calculated according to the following equation:

Permeability = exudate weight $(\mathrm{g}) /\left[\right.$ root surface area $\left(\mathrm{m}^{2}\right) \times$ extraction time $(\mathrm{s}) \times$ applied pressure $\left.(\mathrm{MPa})\right]$

Water potential was used as a proxy for the total amount of solutes in the exudate. The exudate was collected with a microsyringe (Hamilton Company, Reno, Nevada, USA) and water potential was measured by using an isopiestic psychrometer (Model-3; Isopiestics Co., Lewes, Delaware, USA) according to Boyer [21]. Sucrose solution of known potential and the exudate were placed into the sample chambers and on the thermocouple, respectively.

Student's $t$-test was used to compare plants growing under the same conditions.

\section{Results}

In a comparison between non-graftedscion cultivars, the aerial part weight of Reiyo was 1.2 times that of Starbuck (Figure 2(a)), where as the root surface area, root permeability, and water potential of exudates were not significantly different (Figures 2(b)-(d)). In a comparison between rootstock cultivars, Maxifort had a higher weight of the aerial parts and larger root surface area than Receive (Figure 2(a), Figure 2(b)), where as the root permeability and exudate water potential were not significantly different (Figure 2(c), Figure 2(d)).

In experiment 1, we compared sympatric grafted combinations. The combination of Dutch cultivars, Starbuck/ Maxifort, had higher values of the weight of the aerial parts (2.1 to 4.4 times), root surface area (2.3 to 3.6 times), and root permeability (1.1 to 1.7 times) than the combination of Japanese cultivars Reiyo/Receive (Figures 3(a)-(c)), whereas the water potential of exudates was not significantly different (Figure 3(d)).

In Experiment 2, the allopatric combinations Reiyo/Maxifort and Starbuck/Receive did not differ significantly in the aerial part weight and root surface area (Figure 4(a), Figure 4(b)). These combinations also did 

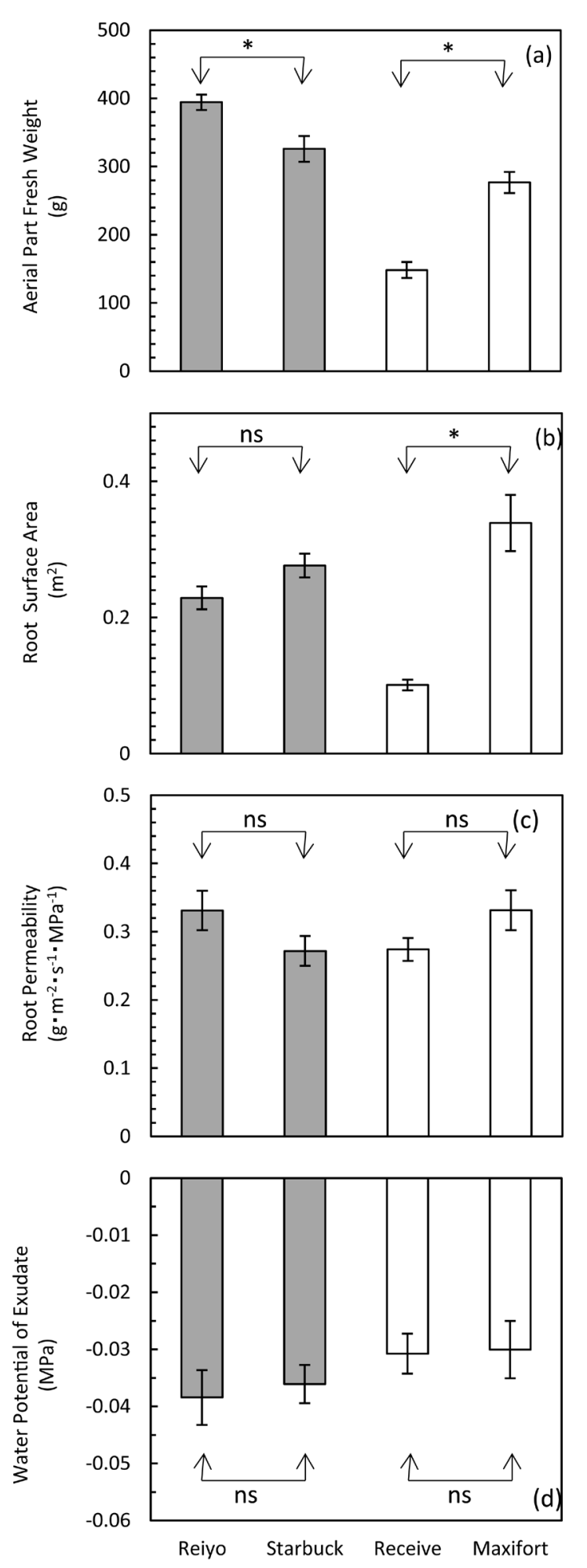

Figure 2. Fresh weight of aerial parts (a), root surface area (b), root permeability (c), and exudate water potential (d) in non-grafted plants. Plants were grown from September to November 2012. Values are means \pm $\mathrm{SE}\left(\mathrm{n}=6 ;{ }^{*} p<0.05\right.$; ns, not significantby Student's $t$-test). 

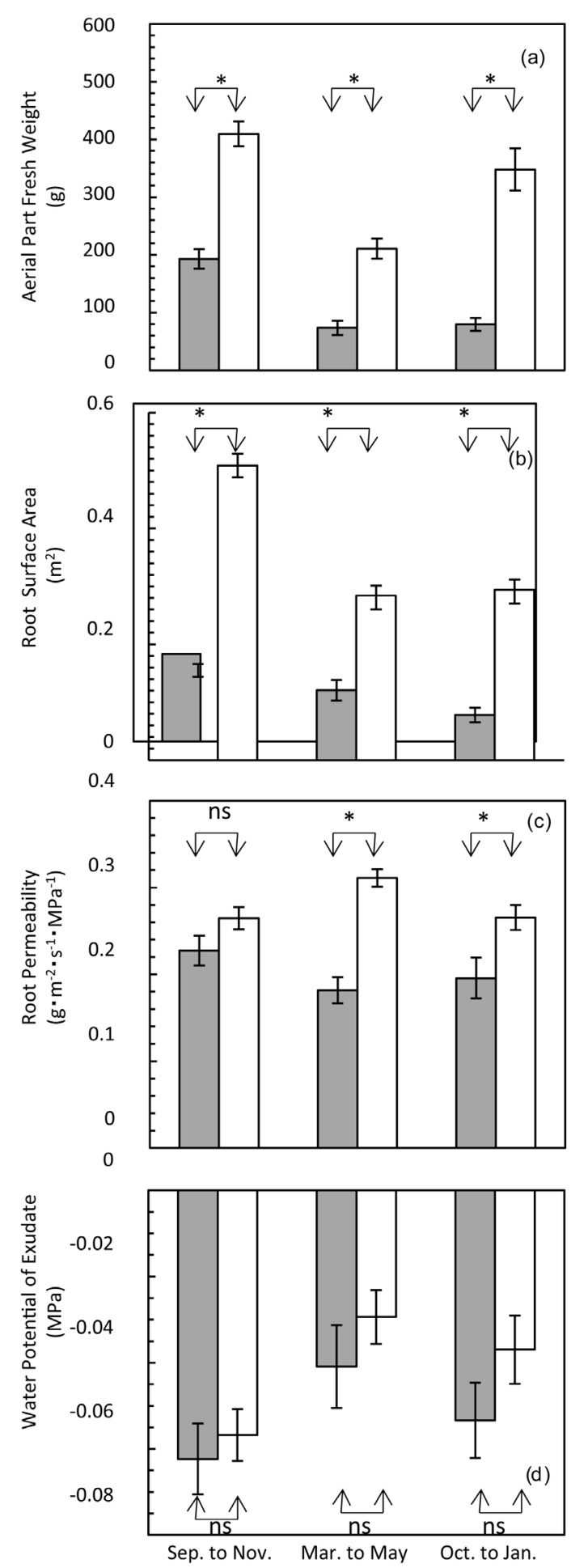

Figure 3. Fresh weight of aerial parts (a), root surface area (b), root permeability (c), and exudate water potential (d) insympatric combinations: Reiyo/Receive (shaded bars) and Starbuck/Maxifort (open bars). Plants were grown from September to November (Reiyo/Receive: $n=10$; Starbuck/Maxifort: $n=12$ ), from March to May (Reiyo/Receive: $n=8$; Starbuck/Maxifort: $n=11$ ), and from October to January ( $\mathrm{n}=8$ for both combinations). Values are means $\pm \mathrm{SE}$ $\left({ }^{*} p<0.05 ;\right.$ ns, not significantby Student's $t$-test). 

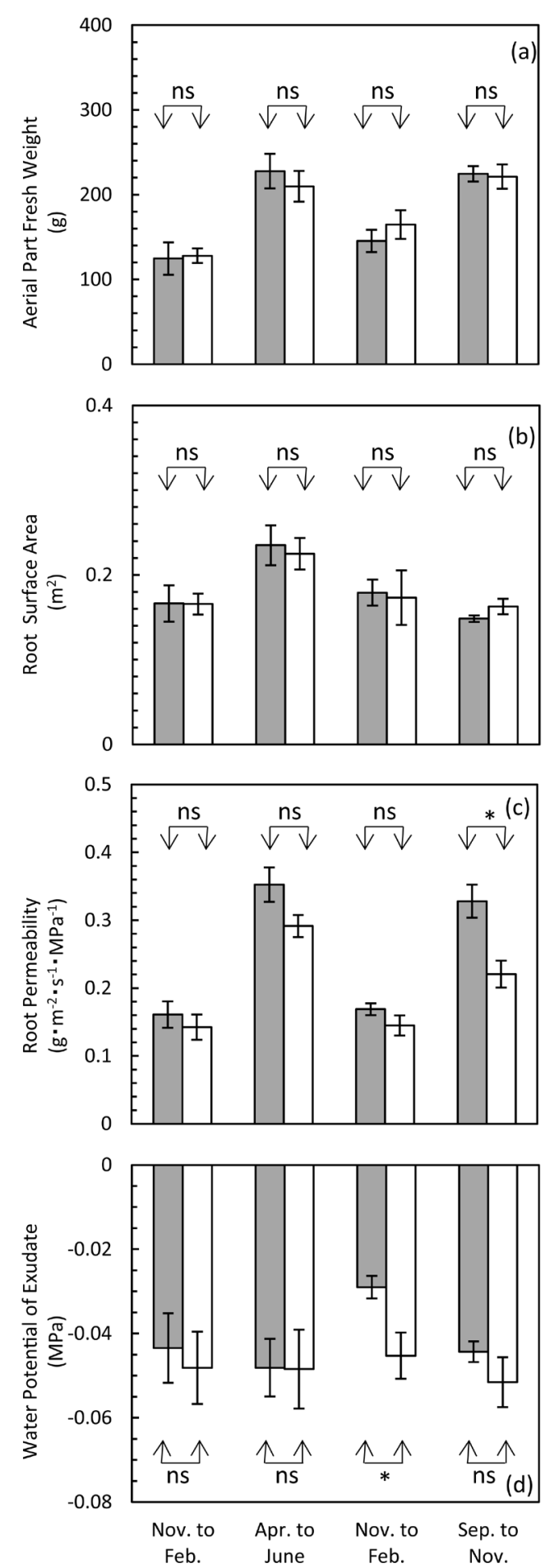

Figure 4. Fresh weight of aerial parts (a), root surface area (b), root permeability (c), and exudate water potential (d) in allopatric combinationsReiyo/Maxifort (shaded bars) and Starbuck/Receive (open bars). Plants were grown from November to February (Reiyo/Maxifort: $n=11$; Starbuck/Receive: $n=8$ ), from April to June (Reiyo/Maxifort: $n=10$; Starbuck/Receive: $n=7$ ), from November to February (Reiyo/Maxifort: $n=7$; Starbuck/Receive: $n=8$ ), and from September to November ( $\mathrm{n}=6$ for both combinations). Values are means $\pm \mathrm{SE}$ $\left({ }^{*} p<0.05\right.$; ns, not significantby Student's $t$-test). 
not differ significantly in root permeability and exudate water potential, except that in 1 out of 4 cultivation periods Reiyo/Maxifort had significantly higher root permeability (Figure 4(c); September to November) and significantly lower exudate water potential (Figure 4(d); November to February) than Starbuck/Receive.

In Experiment 3, the Reiyo/Maxifort combination had a higher root permeability than Reiyo/Receive and Reiyo/Magnet (Figure 5(c)). The same tendency was observed for the aerial part fresh weight and root surface area, although no significant difference was observed between the aerial part fresh weight of Reiyo/Maxifort and Reiyo/Receive in 1 out of the 2 cultivation periods (Figure 5(a); November to February) and between the root surface area of Reiyo/Maxifort and Reiyo/Receive (Figure 5(b)). In both cultivation periods, exudate water potential tended to be lowest in Reiyo/Receive and highest in Reiyo/Maxifort, but the difference reached statistical significance only for Reiyo/Receive in one of the two cultivation periods (Figure 5(d); November to January).

\section{Discussion}

Diverse experimental approaches have been used to compare various physiological characteristics in Dutch and Japanese tomatoes, including fruit weight and mesocarp thickness [22], effects of $\mathrm{CO}_{2}$ concentration on fruit growth, relative source and sink strengths [23], leaf characteristics, and photosynthetic rate [24]. These studies mainly considered the differences between the aerial parts of Dutch and Japanese tomatoes, whereas little is known about the root systems despite their importance for vegetative growth and fruit yield. Most of these studies used non-grafted plants [18] [22]-[25], whereas grafted plants are morphologically and physiologically different.

In this study, we documented the differences in aerial part weight, root surface area, and root permeability in non-grafted Japanese and Dutch tomato cultivars and in their allopatric and sympatric grafted combinations. Collection of exudate from the stem by using root pressure has been used to estimate plant water uptake, but this method is prone to errors if plants actively evaporate [26] [27]. Therefore, to measure root permeability, we chose the pressure chamber technique, which has been previously used in tomato [18] [20] [28]-[30] and rice [31]-[33].

Japanese and Dutch tomato cultivars grown under the same conditions differ in productivity and plant vigor [34]: Japanese cultivars tend to be more vigorous [34]-[36]. This may be explained by differences in water and nutrient uptake. Previous studies mainly investigated the aerial parts of Dutch and Japanese tomatoes, whereas little is known about the root systems. Furukawa et al. [18] demonstrated that the aerial part weight and root permeability in seedlings of the Japanese cultivar Reiyo are significantly higher than in those of the Dutch cultivar Dundee. This was also observed between seedlings of Reiyo and those of the Dutch cultivar Starbuck [30]. In this study, root permeability of Reiyo tended to be higher than that of Starbuck, but the difference was not statistically significant (Figure 2(c)). Thus, one of the reasons for growth differences between the cultivars observed by Furukawa et al. [19] and Ahn et al. [36] may be the difference in root permeability. Further studies of other cultivars from both countries at various growing stages are needed.

In this study, in rootstock cultivars, the value of root surface area (Figure 2(b)) but not that of root permeability (Figure 2(c)) was significantly higher in Maxifort than in Receive. The combination of Dutch cultivars Starbuck/Maxifort had a larger root surface area (Figure 3(b)) and higher root permeability (in two out of three cultivation periods; Figure 3(c)) than the combination of Japanese cultivars Reiyo/Receive. These differences would result in higher water and nutrient uptake, which would increase the aerial part growth (Figure 3(a)). We also found that Reiyo on Maxifort had higher root permeability than Reiyo grafted on two Japanese rootstocks, Receive and Magnet (Figure 5(c)), which probably resulted in a larger fresh weight of aerial parts (Figure 5(a)). Thus, grafted combinations with Maxifort rootstock had increased root surface area and root permeability. However, root surface area and root permeability did not differ significantly between Reiyo/Maxifort and Starbuck/Receive (Figure 4(b), Figure 4(c)). These results do not allow us to conclude that the physiological effects of rootstocks are primarily a function of root permeability. Melon yield depends on the combination of scion and rootstock, and the content of inorganic ions in the leaves is altered by the rootstock [16]. Santa-Cruz et al. [37] observed that the same rootstock differently affects growth of scions from different tomato cultivars. Thus, the root surface area and root permeability in grafted plants may be affected by the scion cultivar. To elucidate the reasons for the difference in fresh weight of the aerial part between the sympatric combinations (Figure 3) and the absence of such difference between the allopatric combinations (Figure 4) in our study, we need to investigate grafting compatibility [16] [38], hydraulic resistance of xylem vessels [39], or other physiological factors. 

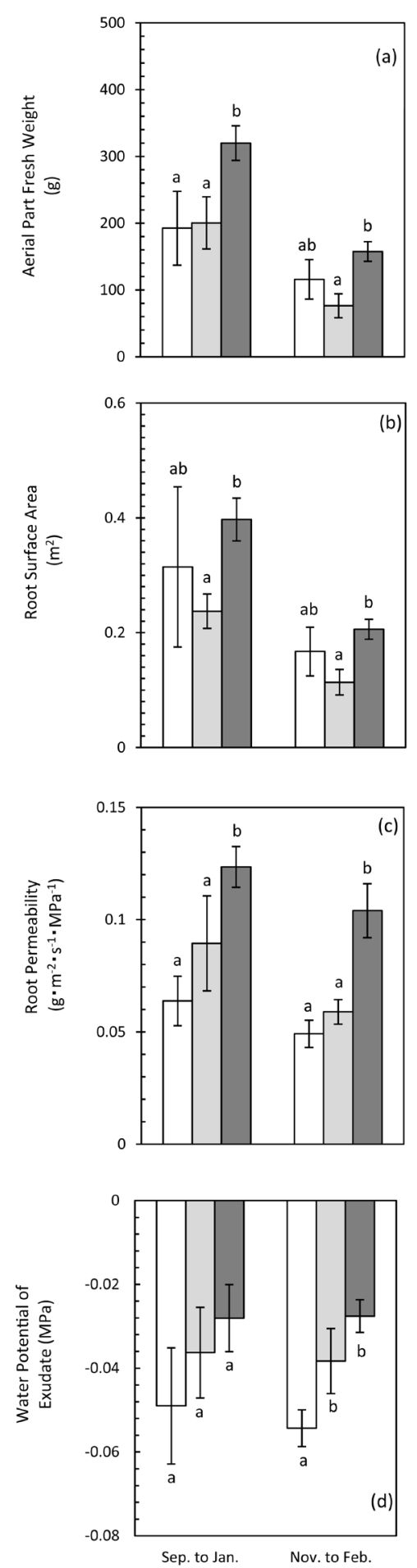

Figure 5. Fresh weight of aerial parts (a), root surface area (b), root permeability (c), and exudate water potential (d) in the combinations Reiyo/Receive (open bars), Reiyo/Magnet (light shaded bars), and Reiyo/Maxifort (darkshaded bars). Plants were grown from September to January (Reiyo/Receive: $n=6$; Reiyo/ Magnet: $\mathrm{n}=5$; Reiyo/Maxifort: $\mathrm{n}=10$ ) and from November to February (Reiyo/ Receive: $n=5$; Reiyo/Magnet: $n=7$; Reiyo/Maxifort: $n=5$ ). Values are means \pm SE. The same letters above bars indicateno significant difference by Student's $t$-testbetween plants grown in same period. 
The pressure chamber method requires analysis of many plants in a short time to prevent the impact of differences in plant growth. In each cultivation period, measurements can be conducted for only a few plants. We therefore decided to improve the accuracy by increasing the number of replications of each experiment. Although air temperature, day length, nutrient solution, and temperature during cultivation are expected to affect the absolute values of the parameters measured, this should not affect the validity of our comparisons within the same groups (i.e. sympatric or allopatric combinations), because comparisons within the groups were performed at the same time. Because root permeability is affected by the root temperature [33] [40], its variability between growing seasons was probably due to temperature differences during greenhouse cultivation. Notably, the relative differences between different grafted combinations were not affected by ambient temperature.

It is noteworthy that the water potential of exudates was similar in most experiments (except in one out four cultivation periods in Figure 4(d) and one out of two cultivation periods in Figure 5(d)). Since water potential reflects solute concentration [21], this shows that solute concentration in exudates was similar in grafted plants with different rootstocks, indicating that all rootstock cultivars provided similar nutrient concentrations to the scions. We may need to consider the effect of scion cultivar on growth and rootstock root surface area in future studies.

\section{Conclusion}

We found that the combination of Dutch cultivars (Starbuck grafted onto Maxifort) had a higher root surface area and root permeability than a combination of Japanese cultivars (Reiyo grafted onto Receive), which may in turn enhance the aerial part growth. Root permeability of the Reiyo/Maxifort combination was higher than that ofReiyo/Receive and Reiyo/Magnet, although the difference between allopatric combinations (Reiyo/Maxifort and Sturbuck/Recieve) was not significant. Further studies are needed to explore the physiological effects of grafting in other cultivars at different growth stages.

\section{References}

[1] Ioannou, N. (2001) Integrating Soil Solarization with Grafting on Resistant Rootstocks for Management of Soil-Borne Pathogens of Eggplant. Journal of Horticultural Science \& Biotechnology, 76, 396-401.

[2] Lee, J.M. (1994) Cultivation of Grafted Vegetables. I. Current Status, Grafting Methods and Benefits. HortScience, 29, 235-239.

[3] King, S.R., Davis, A.R., Liu, W. and Levi, A. (2008) Grafting for Disease Resistance. HortScience, 43, $1673-1676$.

[4] Keinath, A.P. and Hassell, R.L. (2014) Control of Fusarium Wilt of Watermelon by Grafting onto Bottlegourd or Interspecific Hybrid Squash despite Colonization of Rootstocks by Fusarium. Plant Disease, 98, 255-266. http://dx.doi.org/10.1094/PDIS-01-13-0100-RE

[5] Den Nijs, A.P.M. and Smeets, L. (1987) Analysis of Differences in Growth of Cucumber Genotypes under Low Light Conditions in Relation to Night Temperature. Euphytica, 36, 19-32. http://dx.doi.org/10.1007/BF00730643

[6] Tachibana, S. (1982) Comparison of Effects of Root Temperature on the Growth and Mineral Nutrition of Cucumber Cultivars and Figleaf Gourd. Journal of Japanese Society for Horticultural Science, 51, 299-308.

[7] Venema, J.H., Dijk, B.E., Bax, J.M., van Hasselt, P.R. and Elzenga, J.T.M. (2008) Grafting Tomato (Solanum lycopersicum) onto the Rootstock of a High-Altitude Accession of Solanum habrochaites Improves Suboptimal-Temperature Tolerance. Environmental \&Experimental Botany, 63, 359-367. http://dx.doi.org/10.1016/j.envexpbot.2007.12.015

[8] Estañ, M.T., Martinez-Rodriguez, M.M., Perez-Alfocea, F., Flowers, T.J. and Bolarin, M.C. (2005) Grafting Raises the Salt Tolerance of Tomato through Limiting the Transport of Sodium and Chloride to the Shoot. Journal of Experimental Botany, 56, 703-712. http://dx.doi.org/10.1093/jxb/eri027

[9] Martinez-Rodriguez, M.M., Estañ, M.T., Moyano, E., Garcia-Abellan, J.O., Flores, F.B. Campos, J.F., Al-Azzawi, M.J., Flowers, T.J. and Bolarin, M.C. (2008) The Effectiveness of Grafting to Improve Salt Tolerance in Tomato When an "Excluder" Genotype Is Used as Scion. Environmental \& Experimental Botany, 63, 392-401. http://dx.doi.org/10.1016/j.envexpbot.2007.12.007

[10] Zekri, M. and Parsons, L.P. (1992) Salinity Tolerance of Citrus Rootstocks: Effects of Salt on Root and Leaf Mineral Concentrations. Plant \&Soil, 147, 171-181. http://dx.doi.org/10.1007/BF00029069

[11] Aloni, B., Cohen, R., Karni, L., Aktas, H. and Edelstein, M. (2010) Hormonal Signaling in Rootstock-Scion Interactions. Scientia Horticulturae, 127, 119-126. http://dx.doi.org/10.1016/j.scienta.2010.09.003

[12] Dong, H.H., Niu, Y.H., Li, W.J. and Zhang, D.M. (2008) Effects of Cotton Rootstock on Endogenous Cytokinins and 
Abscisic Acid in Xylem Sap and Leaves in Relation to Leaf Senescence. Journal of Experimental Botany, 59, 12951304. http://dx.doi.org/10.1093/jxb/ern035

[13] Proebsting, W.M., Hedden, P., Lewis, M.J., Croker, S.J. and Proebsting, L.N. (1992) Gibberellin Concentration and Transport in Genetic Lines of Pea. Plant Physiology, 100, 1354-1360. http://dx.doi.org/10.1104/pp.100.3.1354

[14] Fernández-García, N., Martínez, V., Cerda, A. and Carvajal, M. (2004) Fruit Quality of Grafted Tomato Plants Grown under Saline Conditions. Journal of Horticultural Science \& Biotechnology, 79, 995-1001.

[15] Alan, Ö., Özdemir, N. and Gimen, Y. (2007) Effect of Grafting on Watermelon Plant Growth, Yield and Quality. Journal of Agronomy, 6, 362-365. http://dx.doi.org/10.3923/ja.2007.362.365

[16] Ruiz, J.M., Belakbir, A., Lopez-Cantarero, A. and Romero, L. (1997) Leaf-Macronutrient Content and Yield in Grafted Melon Plants: A Model to Evaluate the Influence of Rootstock Genotype. Scientia Horticulturae, 71, 227-234. http://dx.doi.org/10.1016/S0304-4238(97)00106-4

[17] Ruiz, J.M. and Romero, L. (1999) Nitrogen Efficiency and Metabolism in Grafted Melon Plants. Scientia Horticulturae, 81, 113-123. http://dx.doi.org/10.1016/S0304-4238(98)00200-3

[18] Furukawa, T., Ishikawa, K., Onuki, S., Mukai, K. and Ikeda, T. (2010) Permeability of Root Cells of Dutch "Dundee” and Japanese "Reiyo" Varieties of Tomato Seedlings to Hydroponic Solution and Potassium Ions. Journal of Japanese Society for Horticultural Science, 79, 287-293. http://dx.doi.org/10.2503/jjshs1.79.287

[19] Furukawa, T., Ikeda, T. and Tomita, H. (2008) Growth, Quality and Rhizosphere State on Dutch and Japanese Varieties of Tomato Plants at Low Truss and High Planting Density under NFT. Horticulture Research, 7, 524. (In Japanese)

[20] Kakita, T., Mukai, K., Sato, Y., Nakamura, M. and Ikeda, T. (2011) Difference of Root Permeability of Dutch and Japanese Varieties of Single-Truss Tomato Plants. Proceedings of the Annual Conference of the American Society for Horticultural Science, Waikoloa, 25-28 September 2011, 116.

[21] Boyer, J.S. (1995) Measuring the Water Status of Plants and Soil. Academic Press, San Diego. http://dx.doi.org/10.1016/b978-012122260-4/50005-6

[22] Oyabu, T., Kato, M. and Sakakibara, M. (2009) Selection of Breeding Materials and Screening Method of Slicing Favorable Tomato Cultivar. Research Bulletin of Aichi Agricultural Research Center, 41, 61-66. (In Japanese)

[23] Matsuda, R., Nakano, A., Ahn, D.H., Suzuki, K., Yasuba, K. and Takaichi, M. (2011) Growth Characteristic and Sink Strength of Fruit at Different $\mathrm{CO}_{2}$ Concentrations in a Japanese and a Dutch Tomato Cultivar. Scientia Horticulturae, 127, 528-534. http://dx.doi.org/10.1016/j.scienta.2010.12.009

[24] Saito, T., Yong-Gen, Y., Matsuoka, M., Watanabe, S., Matsukura, C. and Fukuda, N. (2011) An Investigation of Differences in Fruit Yield and Components Contributing to Increased Yield in Japanese and Dutch Tomato Cultivars. Plant Biotechnology, 28, 455-461. http://dx.doi.org/10.5511/plantbiotechnology.11.0928a

[25] Matsuda, R., Suzuki, K., Nakano, A., Higashide, T. and Takaichi, M. (2011) Responses of Leaf Photosynthesis and Plant Growth to Altered Source-Sink Balance in a Japanese and a Dutch Tomato Cultivar. Scientia Horticulturae, 127, 1298-1300. http://dx.doi.org/10.1016/j.scienta.2010.12.008

[26] Else, M.A., Hall, K.C., Arnold, G.M., Davies, W.J. and Jackson, M.B. (1995) Export of Abscisic Acid, 1-Aminocyclopropane-1-Carboxylic Acid, Phosphate, and Nitrate from Roots to Shoots of Flooded Tomato Plants. Plant Physiology, 107, 377-384.

[27] Jeschke, W.D. and Pate, J.S. (1991) Cation and Chloride Partitioning through Xylem and Phloem within the Whole Plant of Ricinus communis L. under Conditions of Salt Stress. Journal of Experimental Botany, 42, 1105-1116. http://dx.doi.org/10.1093/jxb/42.9.1105

[28] Kanai, S., Moghaieb, R.E., El-Shemy, H.A., Panigrahi, R., Mohapatra, P.K., Ito, J., Nguyen, N.T., Saneoka, H. and Fujita, K. (2011) Potassium Deficiency Affects Water Status and Photosysthetic Rate of the Vegetative Sink in Greenhouse Tomato Prior to Its Effects on Source Activity. Plant Science, 180, 368-374. http://dx.doi.org/10.1016/j.plantsci.2010.10.011

[29] Nonami, H., Fukuyama, T. and Hashimoto, Y. (1998) Presence of Water Chemicals and Water Permeability in Tomato Roots under Salt-Stressed Conditions. Proceedings of Environmental Control in Biology, 282-283.

[30] Onuki, S., Mukai, K., Sato, Y., Furukawa, T. and Ikeda, T. (2010) Effect of Mercuric Chloride to Root Water Permeability on Dutch and Japanese Varieties of Tomato Seedlings. Horticulture Research, 9, 369. (In Japanese)

[31] Asanuma, S., Ookawa, T. and Hirasawa, T. (2007) The Resistance to Water Flow of the Osmotic Water Absorption and Transport in Rice Plants for Rapid Determination of Root Resistance to Water Transport. Japanese Journal of Crop Science, 76, 246-247. (In Japanese)

[32] Miyamoto, N., Steudle, H., Hirasawa, T. and Lafitte, R. (2001) Hydraulic Conductivity of Rice Roots. Journal of Experimental Botany, 52, 1835-1486. http://dx.doi.org/10.1093/jexbot/52.362.1835

[33] Murai-Hatano, M., Kuwagata, T., Sakurai, J., Nonami, H., Ahamed, A., Nagasuga, K., Matsunami, T., Fukushi, K., 
Maeshima, M. and Okada, M. (2008) Effect of Low Root Temperature on Hydraulic Conductivity of Rice Plants and the Possible Role of Aquaporins. Plant Production Science, 49, 1294-1305. http://dx.doi.org/10.1093/pcp/pcn104

[34] Ahn, D., Nakano, A., Matsuda, R., Higashide, T., Suzuki, K. and Takaichi, M. (2010) Effect of the Change of Sink Strength by Fruit Thinning on Growth in a Japanese and a Dutch Tomato Cultivar. Horticulture Research, 9, 238. (In Japanese)

[35] Ando, A., Wada, T., Hirai, H. and Abe, K. (2003) Effect of Rockwool-Cube Size and Days of Raising Seedlings on Growth and Root Activity of the Seedlings, Growth after Transplanting and Yield of Tomato Growth on Rockwool. Horticulture Research, 2, 297-301. http://dx.doi.org/10.2503/hrj.2.297

[36] Kobayashi, S. and Kirimura, Y. (1999) Effects of Rockwool Cube Size and Root Limitation on Plant Growth and Fruit Yield of Lower-Truss Tomato by Hydroponics. Horticulture Research, 68, 307. (In Japanese)

[37] Santa-Cruz, A., Martinez-Rodriguez, M.M., Perez-Alfocea, F., Romero-Aranda, R. and Bolarin, M.C. (2002) The Rootstock Effect on the Tomato Salinity Response Depends on the Shoot Genotype. Plant Science, 162, 825-831. http://dx.doi.org/10.1016/S0168-9452(02)00030-4

[38] Oda, M. (2001) Grafting of Vegetable Crops. Scientific Report of the Graduate School of Agriculture\& Biological Science Osaka Prefecture University, 54, 49-72.

[39] Oda, M., Maruyama, M. and Mori, G. (2005) Water Transfer at Graft Union of Tomato Plants Grafted onto Solanum Rootstocks. Journal of Japanese Society for Horticultural Science, 74, 458-463. http://dx.doi.org/10.2503/jishs.74.458

[40] Nagasuga, K., Murai-Hatano, M. and Kuwagata, T. (2011) Effect of Root Temperature on Dry Matter Production and Root Water Uptake in Rice Plants. Plant Production Science, 14, 22-29. http://dx.doi.org/10.1626/pps.14.22 